\title{
Percepción remota y procesamiento de imágenes para la gestión de cultivos de caña de azúcar
}

\section{Remote perception and image processing for the management of sugar cane crops}

LÁRRAGA-ALTAMIRANO, Hugo Rene †*, HERNÁNDEZ-LÓPEZ, Dalia Rosario, PIEDAD-RUBIO, Ana María and AMADOR-SONI, Jesús Antonio

\author{
Tecnológico Nacional de México, Campus Ciudad Valles
}

ID $1^{\text {st }}$ Author: Hugo Rene, Lárraga-Altamirano / ORC ID: 0000-0001-8258-9418, Researcher ID Thomson: T-2296-2018, arXiv Author ID: Hugo_Larraga, CVU CONACYT ID: 626539

ID $1^{\text {st }}$ Co-author: Dalia Rosario, Hernández-López / ORC ID: 0000-0002-2751-5886, Researcher ID Thomson: T-24702018, arXiv Author ID: DaliaHernandez, CVU CONACYT ID: 536472

ID $2^{\text {nd }}$ Co-author: Ana María, Piedad-Rubio / ORC ID: 0000-0003-1258-0383, Researcher ID Thomson: T-2477-2018, arXiv Author ID: ampiedad, CVU CONACYT ID: 732279

ID $3^{\text {rd }}$ Co-author: Jesús Antonio, Amador-Soni / ORC ID: 0000-0002-7264-6148, arXiv Author ID: sonibaba, Open ID: 106324682174175915693, CVU CONACYT ID: 1167881

DOI: $10.35429 / J O E S .2021 .25 .8 .30 .36$

Received 09 July, 2021; Accepted 28 December, 2021

\begin{abstract}
This research work shows that with the use of remote sensing technology it is possible to more effectively fulfill two of the purposes pursued by farmers in the field; manage crops more efficiently and include environmental care in decision-making. Specifically, remote sensing is applied in the context of precision agriculture through geographic information systems (GIS), unmanned aerial vehicles (UAV), multispectral sensors that capture the reflectance of the infrared band of the light spectrum (for interpretation of the biochemical state of the crop), global geopositioning systems (GPS), among others. This study limits the use of this technology to the processing of multispectral images obtained by aerial photogrammetry, and its subsequent treatment for the generation of orthoimages, the calculation of the NDVI vegetation index and the classification of land cover by clustering. Finally, the effect of classification with RGB and multispectral images is analyzed.
\end{abstract}

Remote sensing, Clustering, GIS, UAV, NDVI

\begin{abstract}
Resumen
El presente trabajo de investigación demuestra que con la utilización de tecnología de percepción remota es posible cumplir con mayor eficacia dos de los propósitos que persiguen los productores del campo: administrar los cultivos con mayor eficiencia e incluir el cuidado ambiental en la toma de decisiones. Específicamente, la percepción remota es aplicada en el contexto de la agricultura de precisión mediante sistemas de información geográfica (SIG), vehículos aéreos no tripulados (VANT), sensores multiespectrales que captan la reflectancia de la banda infrarroja del espectro de luz (para la interpretación del estado bioquímico del cultivo), sistemas de geoposicionamiento global (GPS), entre otros. Este estudio acota el uso de esta tecnología al procesamiento de imágenes multiespectrales obtenidas por fotogrametría aérea, y su tratamiento posterior para la generación de ortoimágenes, el cálculo del índice de vegetación NDVI y la clasificación de coberturas terrestres por clusterizacion. Por último, se analiza el efecto de la clasificación con las imágenes RGB y multiespectral.
\end{abstract}

Percepción remota, Clusterizacion, SIG, VANT, NDVI

Citation: LÁRRAGA-ALTAMIRANO, Hugo Rene, HERNÁNDEZ-LÓPEZ, Dalia Rosario, PIEDAD-RUBIO, Ana María and AMADOR-SONI, Jesús Antonio. Percepción remota y procesamiento de imágenes para la gestión de cultivos de caña de azúcar. Journal of Experimental Systems. 2021. 8-25: 30-36

\footnotetext{
* Correspondence to Author (e-mail: hugo.larraga@ tecvalles.mx).

$\dagger$ Researcher contributing as first Author.
} 


\section{Introduction}

Sugarcane is the crop with the highest production worldwide, in Mexico alone in 2017, 772,003 hectares were harvested which produced 56,954,993 tons of this grass mostly used by the sugar industry (FAO, 2019). In the Huasteca Potosina region located in the state of San Luis Potosí, agriculture is the main economic activity, with the cultivation of sugarcane standing out from others, such as corn, beans, sorghum, fruits and citrus (Aparicio, 2013).

Therefore, the efficient and sustainable production of sugarcane is an important issue, since on the one hand there is a tendency to better manage the field with fewer resources and, on the other, to reduce the negative impact of agricultural activities on planetary care. In other words, farmers must make decisions based on a greater amount of information to ensure economic viability without neglecting environmental friendliness. Information and communication technologies play a central role in the construction of intelligent farm models that provide the producer with information acquired from different media, allowing to monitor the plots in real time to plan their activities in response to changing circumstances (O'Grady, M. \& O'Hare,M., 2017).

\begin{abstract}
The present research work helps to achieve more effectively the two aforementioned purposes; to manage crops more efficiently and to include environmental care in decision making. Specifically, remote sensing is applied in the context of precision agriculture through geographic information systems (GIS), unmanned aerial vehicles (UAVs), multispectral sensors that capture the reflectance of the infrared band of the light spectrum (for the interpretation of the biochemical status of the crop), global geopositioning systems (GPS), among others (O'Grady, M. \& O'Hare,M., 2017).
\end{abstract}

This technology for the acquisition and processing of sensed data gives support to crop management, in activities such as: pest detection, fertilizer use, productivity variation, yields, soil chemistry, to mention some of the factors that are of interest to producers (Aguilar, 2015).
Currently, different technological solutions are implemented to obtain information on crops and thus create an intelligent model for their management, each of which makes use of sophisticated measuring equipment, either to know the moisture level in the soil, the temperature or the nutritional status of the plant through sensor networks, satellites, airships, among others (Aparicio, 2013). However, this study The objective of this work is to apply remote sensing and image processing techniques for monitoring sugarcane crops.

This includes, the operation of UAVs, the integration of crop orthoimages ("map"), with multispectral information to calculate the normalized difference vegetation index (NDVI) and land cover classification by clustering. The above tasks generate a mass of data useful for field producers (Majumdar, Naraseeyappa, \& Ankalaki, 2017). The latter allows analyzing the effect of classification with RGB and multispectral images. Each stage of development integrates technology that requires estimations to be made to adapt to sugarcane monitoring in the Huasteca Potosina region, so that producers will have a greater amount of data that favors efficient decision making (Cheli, 2011).

\section{Methodology}

Agriculture depends on many climatic, geographical, biological, political and economic factors, which introduce risks. Processed crop information is part of the efficient management of these risks, which is essential for successful agricultural production. Effective information management allows estimating the probability of undesirable situations and minimizing the consequences. Therefore, reliable information on historical crop yields is vital for decisions related to agricultural risk management (A.A. \& R.V., 2013).

For the development of the project, 3 stages were defined, as shown in Figure 1.

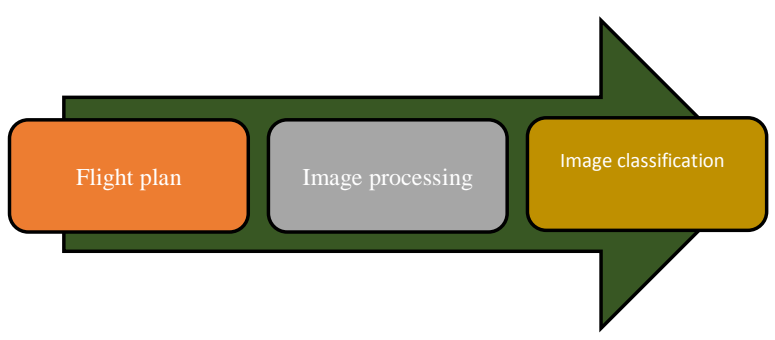

Figure 1 Methodology

Source: Own 


\subsection{Flight Plan}

It is important to observe the presence of obstacles, their heights and locations, wind conditions, infrastructure that generates electromagnetic radiation, as well as the extension (area and shape) so that the calculation of the photogrammetric parameters is accurate. It is possible to execute a reconnaissance flight with the assistance of a flight control software that helps to estimate the aforementioned information, locate the point of origin (HOME POINT), the appropriate altitude and the type of trajectory to follow, take-off and landing zone, estimated flight time, among others.

The geographic location of the area to be covered is obtained through a geospatial information system (GIS) such as Google Earth, which allows the construction of .KML or .KMZ files useful for the planning of autonomous flights. Another option is to determine the territorial coverage with the autonomous flight software, in this case Pix 4D Capture will be used because of its easy operation and high efficiency. Both software can interact together to calculate the geographic coordinates that delimit the crop to be inspected, as well as to configure some of the parameters required for the flight such as: overlapping minimum, intermediate speed depending on the drone model, camera angle, orientation and flight altitude (González, Amarillo, Amarillo, \& Sarmiento, 2015).

The calibration of the aircraft sensors, as well as the correct configuration of the RGB and multispectral cameras are key aspects to perform a flight under standardized safety conditions and obtain the appropriate quantity and quality of images for further processing (Herrero Huerta, 2016).

\subsection{Image processing}

The map construction process is performed with the widely recognized processing or transformation software Pix4D Mapper. The images obtained are used to generate cartographic products such as: reflectance map, elevation model, point cloud, among others. In turn, the multispectral images formed by the light reflection of the red, near infrared, infrared and green bands create the NDVI index map used in precision agriculture to determine crop conditions.
Geographic information systems process the images using the geospatial data attached in the metadata by combining them, much like integrating a mosaic, to present a single image (orthoimage) of the crop (Tapia Arenas, Guevara Bonilla, \& Esquivel Segura, 2019). It is important to note that multispectral images are affected by some factors that change during each shot, such as clouds, time of capture, altitude and illumination, so in order to have greater accuracy a radiometric correction is required using control images taken designed for the type of camera.

\subsection{Image classification}

The classification of the mosaic created from the image processing has the purpose of distinguishing the vegetation units corresponding to the sugar cane crop, other types of vegetation and soil. The result of the previous phase is two ortho images of the crop, one in RGB bands and the other in NDVI bands. For the RGB classification, a supervised method called Minimum Distance is used, which uses mean spectral values of the different classes, ignoring the variances between them. (Willington, Nolasco, \& Bocco, 2013). For this, the three training classes are first established: sugarcane (class 1), natural soil (class 2) and other vegetation (class 3 ), represented by buffers of pixels extracted from the original image.

On the other hand, the classification of the multispectral mosaic is performed with an unsupervised method known as k-means, which classifies a given set of objects into k-clusters (classes), each cluster is represented by the average of its points, i.e., its centroid (Cambronero, 2006). This method does not require training, in fact, the objective is to classify a set of pixels based on the similarity of their spectral characteristics.

\section{Results}

\subsection{Flight plan}

This phase comprises the performance of different activities, which are listed below:

1. Reconnaissance of the area to be flown. Before starting the flight, it is advisable that the pilots know the physical place where they will fly, this allows them to identify obstacles such as mountains, trees, towers, cables, among others. 
2. Firmware update. It is important that the vehicles have the latest firmware version and the database of safe flight zones updated. This process, as well as the safe flight databases, is achieved through the DJI Assistance 2 application, which offers an intuitive interface for DJI products. See Figure 2 and Figure 3.

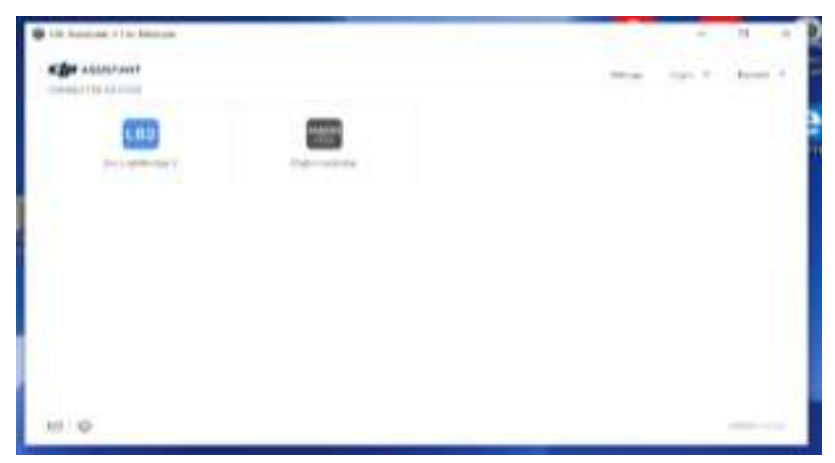

Figure 2 DJI Assistence 2 firmware main window Source: own

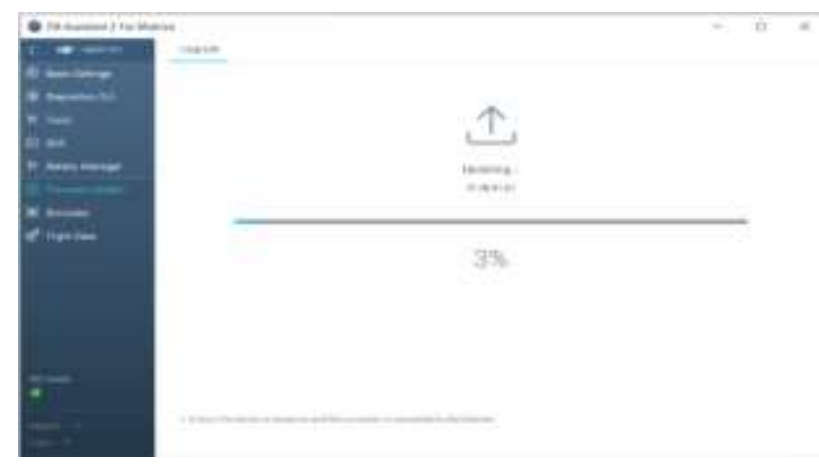

Figure 3 Firmware update status Source: own

3. Geolocate the terrain to be studied. Using software support (Google Earth) it is recommended to locate the study area to obtain its geographic coordinates. The software has a useful search tool to identify the area to be explored, just type the name of the place or nearby places to get a view in Google Maps format. With the polygon tool, the study area can be delimited and a name can be added to identify it from other projects. See Figure 4 and Figure 5.

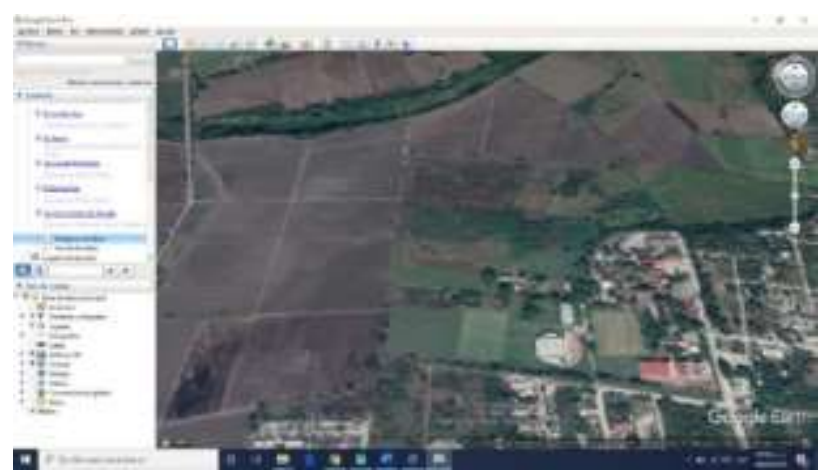

Figure 4 Geolocation of the firmware study area Source: Google Earth

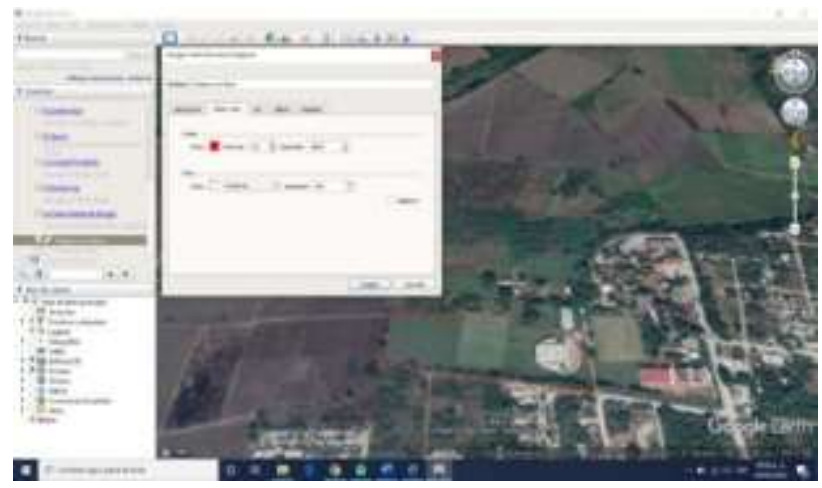

Figure 5 Delimitation of the firmware study area Source: Google Earth

4. Calibration. To have an accurate flight it is necessary to perform the required calibrations to the equipment, this includes calibrating: compass, IMU, remote control and cameras. The calibration of the drone is done using the DJI Go application tools, it is recommended that the compass, IMU and remote control are in 'Normal' conditions before the flight. Additionally, the SEQUOIA multispectral camera should be configured and calibrated independently of the vehicle. See Figure 6 and Figure 7.

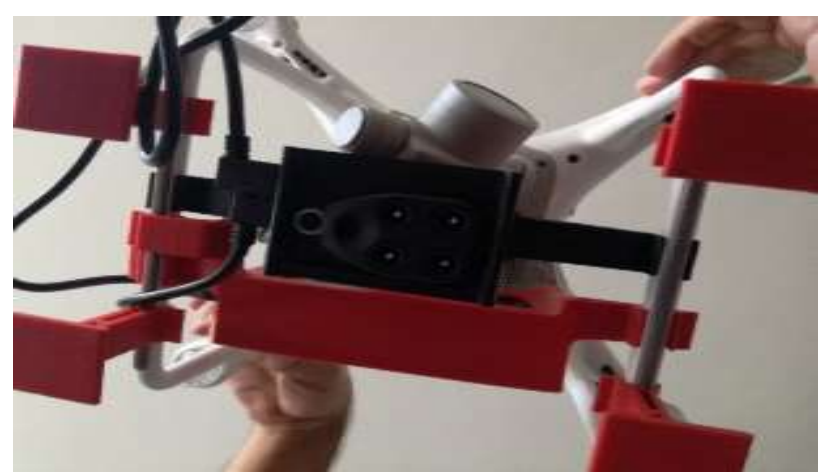

Figure 6 Sensor support Source: Own 


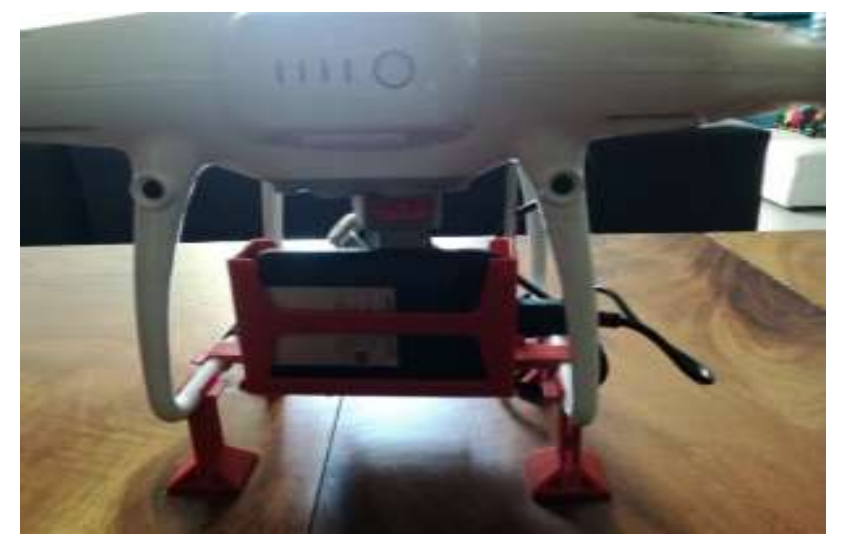

Figure 7 Connection of the multispectral sensor Source: Own

5. Programmed flight. The aerial route that the drone will take is programmed in the Pix4D Capture application from where the vehicle will be controlled.

\subsection{Image processing}

Image processing is a process that involves the use of specialized photogrammetry software. Highly complex algorithms join the photographs obtained by the UAVs to create cartographic products used in the study of crops such as: orthomosaics, maps, indexes, among others. In this case, the processing was performed by Pix4D Mapper, a market leader in photogrammetric applications. Figures 8 and 9.

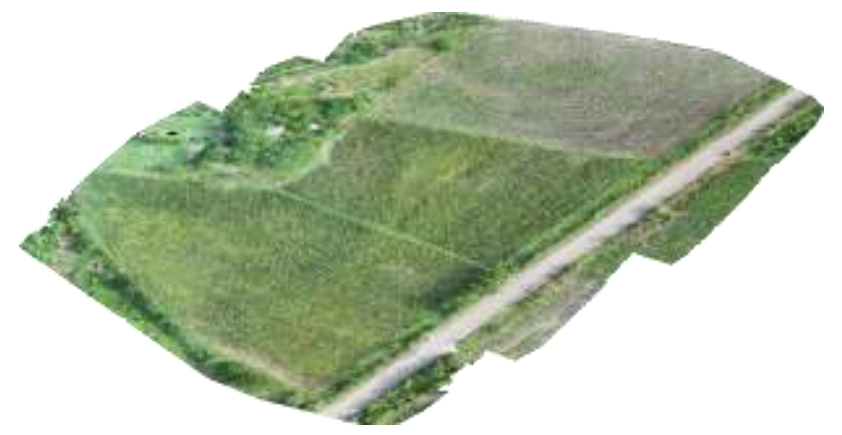

Figure 8 Result of the RGB camera shot Source: Pix4Dmapper

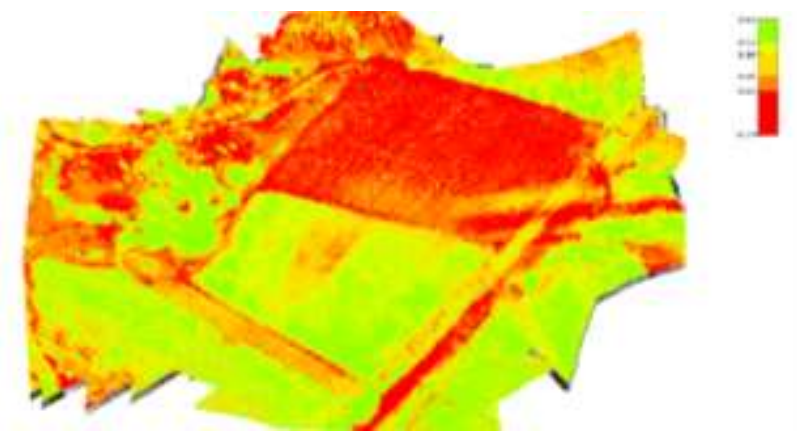

Figure 9 Multispectral camera acquisition result Source: Pix4Dmapper: Pix4Dmapper
It is interesting to note that PIX4D offers 3 options to present the NDVI, which, in a way is also a classification of the calculated values. Equal Spacing classifies the NDVI using the same range of minimum and maximum values for all classes. Equal Area, distributes the land area among the number of classes showing the minima and maxima of each section. Jenks, an unsupervised classification algorithm that groups values with a similar Euclidean distance, uses the same principle as k-means, see Figure 10.

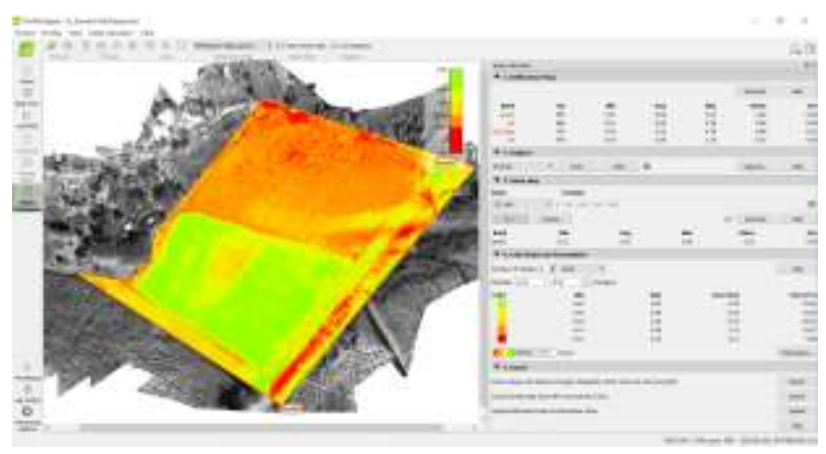

Figure 10 Jenks, clustering of values Source: Pix4Dmapper

\subsection{Image classification}

The classification process involves the use of supervised and unsupervised algorithms operated from QGIS. For this particular case we want to identify the sugarcane crop as efficiently as possible considering that the orthoimages resulting from the previous step are RGB (three bands) and NDVI (single band), see Figure 8 . For the training stage of the supervised technique three macro classes were created: sugarcane (green), soil (gray), other vegetation (yellow). The QGIS Semi-Automatic Classification Plugin (SCP) tool consists of a set of tools for classifying orthoimages. For each of these, four regions of interest were defined and then the Minimum Distance algorithm was run, the results are shown in Figure 11.

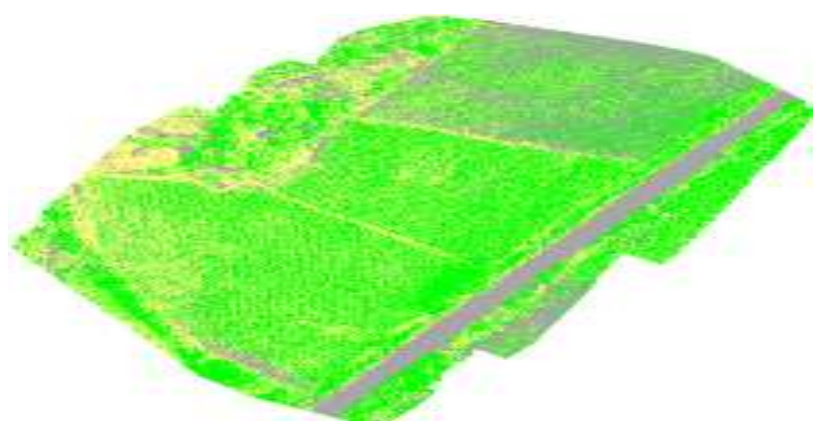

Figure 11 Classification by Minimum Distance RGB orthoimage

Source: QGIS

LÁRRAGA-ALTAMIRANO, Hugo Rene, HERNÁNDEZ-LÓPEZ Dalia Rosario, PIEDAD-RUBIO, Ana María and AMADOR-SONI, Jesús Antonio. Percepción remota y procesamiento de imágenes para la gestión de cultivos de caña de azúcar. Journal of Experimental Systems. 2021 
The unsupervised classification was applied to the single band NDVI image. The Band Processing > Clustering tool of the SCP suite implements the k-means algorithm which groups pixels of the same reflectance level into as many groups as specified. For this example 5 groups were determined, the output shows the centroids of each group and the average distance between the pixels of each group, see Figure 12.
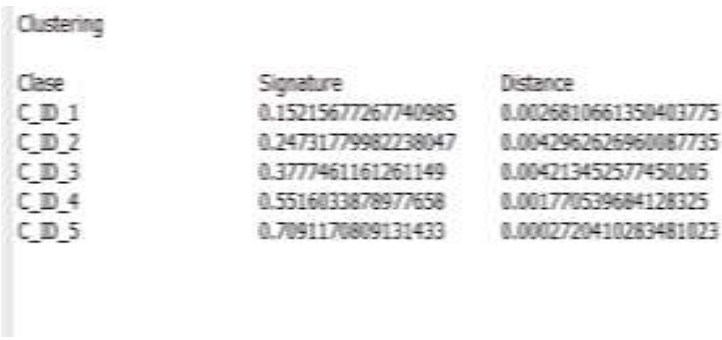

Figure 12 Example of centroid outputs Source: $Q G I S$

The image of the final result is interesting to analyze, it is observed that the vegetation is easily distinguished, both healthy and unhealthy, likewise it is shown that the arid soil and asphalt have similarities, see Figure 13.

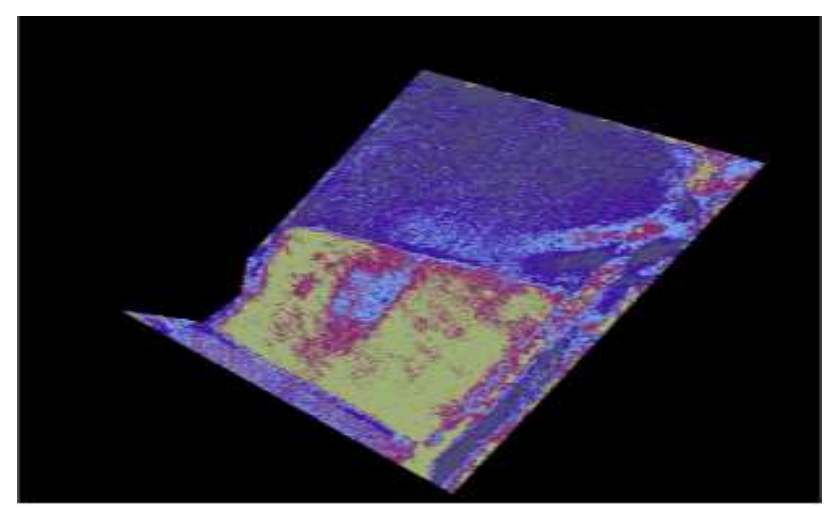

Figure 13 Classification using QGIS Source: QGIS

\subsection{Discussion of the results}

The classification supervised by Minimum Distance on the RGB orthoimage, presents confusion between classes, i.e., in some groups of pixels it does not reliably distinguish whether they belong to the reed class or to another vegetation. Similarly, although with less error, the soil class is not identified when it borders with a large amount of other vegetation. It follows that the training process is costly in the sense that more samples per class are required to be labeled correctly.
The unsupervised k-means classification on the NDVI orthoimage clearly distinguishes the vegetation from the rest of the objects contained in the photograph. It is interesting to note that the spectral characteristics of the infrared band do indeed provide information that can be interpreted to assess crop condition. Even though there is confusion between the cane class and the other vegetation, the crop section shows more spectral details that can be analyzed to improve productivity.

\section{Conclusions}

This model presented involves the use of remote sensing and image processing techniques to obtain crop information. These remote sensing and image processing techniques can be applied to different types of crops. As a management model, the biochemical information of the agricultural crop expressed in NDVI values can be considered as a critical element to improve productivity, influencing decomposition processes and nutrient cycling, biochemical changes in the canopy, build a temporal database or be used with mathematical models for decision making in relation to input management and sugarcane management practices.

\section{References}

A.A., R., \& R.V., K. (2013). Review- Role of Data Mining in Agriculture. IJCSIT International Journal of Computer Science and Information Technologies, 270-272.

Aguilar, N. (2015). Percepción remota como herramienta de competitividad de la agricultura. Revista mexicana de ciencias agrícolas, 6(2), 399-405.

Aparicio, F. \&. (2013). Wireless Sensor Networks Applied to Optimization in Precision Agriculture for Coffee Crops in Colombia. Journal de Ciencia e Ingeniería, 5(1), 46-52.

Cambronero, C. G. (2006). Algoritmos de aprendizaje: $\mathrm{knn} \&$ kmeans. Intelgencia en Redes de Comunicación (pág. 23). Madrid: Universidad Carlos III de Madrid.

Cheli, A. E. (2011). Introducción a la Fotogrametría y su evolución. 
FAO. (2019). FAOSTAT. Obtenido de FAOSTAT:

http://www.fao.org/faostat/es/\#home

González, A., Amarillo, G., Amarillo, M., \& Sarmiento, F. (2015). Drones Aplicados a la Agricultura de Precisión. Revista Especializada en Ingeniería, 23-37.

Herrero Huerta, M. (2016). Fotogrametría de rango cercano aplicada a la Ingeniería Agroforestal. Salamanca, Guanajuato, México.

Majumdar, J., Naraseeyappa, S., \& Ankalaki, S. (2017). Analysis of agriculture data using data mining techniques: application of big data. Springer, 1-15.

O'Grady, M., \& O'Hare,M. (2017). Modelling the smart farm. Information Processing in Agriculture, 4 4(3), 179-187. doi://doi.org/10.1016/j.inpa.2017.05.001

Tapia Arenas, A., Guevara Bonilla, M., \& Esquivel Segura, E. (2019). Procesamiento de imágenes a partir de vehículos aéreos no tripulados utilizando software libre. Costa Rica: Tecnológico de Costa Rica.

Willington, E., Nolasco, M., \& Bocco, M. (2013). Clasificación supervisada de suelos de uso agrícola en la zona central de Córdoba (Argentina): comparación de distintos algoritmos sobre imágenes Landsat. Congreso Argentino de AgroInformatica (págs. 207-216). Argentina: JAIIO - CAI. 